\title{
My-place-ness Approach for Social Service Design: Lessons from the Evolution of Internet Services
}

\author{
Toshihiko Yamakami Software Solution, ACCESS \\ Nakase 1-10-2, Mihama-ku, Chiba-shi \\ Chiba, Japan 261-0023 \\ Email: Toshihiko.Yamakami@access-company.com
}

\begin{abstract}
Since the Internet has penetrated into everyday life, it is crucial to design services in the socially-empowered way. However, technology-driven engineering has placed too many functions into services without considering an appropriate evaluation of the comfort of long-stays. The technology-augmented space has too many possible interactions that threaten the fundamental comfort of human beings. A distinction between the treatment of space and the treatment of place is required in order to provide the building blocks of social services in the virtual world. The author proposes a so-called "my place" theory based on my-place-ness to cope with these conflicts between human beings and technology-empowered spaces. The author provides a two-dimensional view model of my-place-ness and a layered view of a functional model of my-place-ness.
\end{abstract}

Keywords-My-place-ness, Internet, comfortability, space and place, service engineering

\section{INTRODUCTION}

In the past, social services were designed from the viewpoint of interpersonal relationships and interactions. The author envisions that the fundamental challenge facing social services on the Internet is to secure a so-called my place, where each end user finds comfort in staying there. From this viewpoint, the author develops a my place theory in order to facilitate increased comfort for end users on the Internet.

The worldwide penetration of the Internet into social life reminds us of the shift of the infrastructure role of the Internet from data access to social interaction. This leverages the need for designing a livable place for ordinary people. From this viewpoint, a random build-up of arbitrary functions and services is not sufficient.

The author has come to recognize that the past evolution of Internet services provides clues that help identify the key factors for comfort in my place. We have an intuitive sense of living place. However, it is necessary to identify the factors that contribute to the living place for human beings.

First, the author examines the characteristics of "my place" and past artifacts that served to facilitate those characteristics. Then, the author examines the design dimensions and components of my-place-ness. Finally, the author discusses the layered view model of design of my-place-ness.

\section{BACKGROUND}

\section{A. Purpose of Research}

The aim of this research is to identify the characteristics of personal placeholder on the Internet to facilitate social service engineering.

\section{B. Related Work}

Human beings are fundamentally social creatures. It is crucial to secure a place where one can confirm a comfortable place to be. This factor has been under-evaluated within the scope of social service engineering. Therefore, technology just accumulates countless functions, which has caused much stress such as social fatigue.

Harrison et al. presented the principle: "Space is the opportunity; place is the understood reality" in the scope of CSCW research [1]. They argued that place derives from a tension between connectedness and distinction, which is an important insight for this paper. They presented a sense of place that framed their behavior.

Wireless communication and ubiquitous computing has influenced the concept of place. Agre et al. discussed the impact of the loosened mapping between activity and place [2]. Dourish revisited it from the new perspective such as mobility, with considerations of spatiality and legibility [3]. In the scope of ubiquitous computing, McCarthy et al. presented a dialogical approach to place as an expression of the experienced relationship between people and space [4].

Knox et al. discussed the sense of place with the supporting factor of e-learning: affording different kinds of practice [5].

Bjerrum et al. discussed the counter-productivity of the technology-augmented "new office" [6]. They argued that it lacked a place to dwell and return to.

Lentini et al. indicated five dimensions that encompass human experiences in physical space and place: Geometrical and Geographical, Sensorial, Cultural, Personal, and Relational [7]. The first three dimensions represent aspects of place and space, and the latter two dimensions address emotional aspects.

Antonopoulou discussed the interwoven nature of the real world and the virtual world from considerations of Second Life and Flash mobs as place-making activities [8].

For the negative impact of SNS, Yamakami discussed about SNS fatigue with a staged model of SNS acceptance [9]. For self-esteem in SNSs, Tazghini et al discussed the relationships between self-esteem and Facebook use[10].

Past research discussed the distinction between place and space from the viewpoint of opportunities for interaction. The characteristics of a protection boundary as a comfort-enabler are not discussed in detail.

The originality of this paper lies in its examination of the characteristics of a personal placeholder on the Internet for 


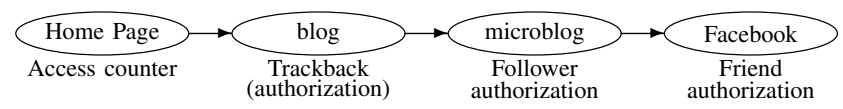

Fig. 1. Evolution of Consumer Services on the Internet

TABLE I

PROBLEMS OF EXTERNALLY FOCUSED DESIGN OF SOCIAL SERVICES

\begin{tabular}{|l|l|}
\hline Aspect & Problem description \\
\hline Commercialism & $\begin{array}{l}\text { People tend to hate being manipulated by commer- } \\
\text { cialism in the social context. }\end{array}$ \\
\hline Social fatigue & $\begin{array}{l}\text { Social burnout can occur when too much interaction } \\
\text { and stress prevail in social services. }\end{array}$ \\
\hline
\end{tabular}

social interactions.

\section{OBSERVATION}

\section{A. Retrospective view}

The evolution of consumer services on the Internet is depicted in Fig. 1.

In the mid-1990's, the Internet was commercialized, which was a departure from its original purpose as a research network. People started to make their own home pages. The Internet literally meant a collection of home pages at that stage. The first interesting artifact people came to love was the access counter. The access counter provided a feeling of recognition, which was the feeling that someone cared enough to visit their homepage.

At the time of Web 2.0, in the midd-2000's, blogs emerged. Blogs focused on the timely submission of recent events, which emphasized synchronicity of the current situation and timeliness. It also facilitated a trackback capability, where people could design automatic notifications among interlinking blog pages. Trackback authorization was developed, which allowed only authorized trackback.

As microblogs emerged, "following" and "being followed" came into emphasis. Microblogs further focused on synchronicity, and also facilitated social interconnection through that synchronicity.

Facebook, and other social network services, started to provide friend registration and authorization. This provided a sense of social interconnection, as well as privacy protection through the segmentation of acquaintances.

\section{B. Problems of externally focused design}

The problems that arise from the externally focused design of social services are depicted in Table I.

Social services have been designed with an externally focused design, which focuses on things such as new interactions and new recommendations. Leverage the comfort-level of a user, requires the inclusion of the internally focused design of social services.

Some problems stem from the limited control of social activities. However, users do not know how to control social activities until they find some problems that are beyond their everyday control. And, when some serious problems occur, it is common for ordinary users to quit without any possible compensation or adjustment.
TABLE II

REASONS FOR QUITTING AN SNS

\begin{tabular}{|l|l|l|}
\hline Category & Aspect & Example \\
\hline Content & Inactivity & $\begin{array}{l}\text { The level of activities is unsat- } \\
\text { isfactory. }\end{array}$ \\
\cline { 2 - 3 } & Loss of interest & Feeling bored. \\
\hline Negativeness & $\begin{array}{l}\text { Loss of we-ness and } \\
\text { relationships }\end{array}$ & Feeling isolated. \\
\cline { 2 - 3 } & $\begin{array}{l}\text { Uncomfortable } \\
\text { social interactions }\end{array}$ & Hatred, stalking. \\
\hline Stress & Stress and fatigue & $\begin{array}{l}\text { Burden of maintaining relation- } \\
\text { ships. }\end{array}$ \\
\hline
\end{tabular}

TABLE III

IMPORTANT FACTORS IN COMFORTABLENESS OF MY PLACE ON THE INTERNET

\begin{tabular}{|l|l|l|}
\hline $\begin{array}{l}\text { Emotional } \\
\text { Factor }\end{array}$ & Factor & Description \\
\hline Safety & Security & $\begin{array}{l}\text { The place provides confidence and control- } \\
\text { lability of security and privacy. }\end{array}$ \\
\cline { 2 - 3 } & Healing & $\begin{array}{l}\text { When exhausted, a sense of healing con- } \\
\text { tributes to a sense of comfort. }\end{array}$ \\
\hline Me-ness & $\begin{array}{l}\text { Taste- } \\
\text { matching }\end{array}$ & $\begin{array}{l}\text { The place provides matches to one's own } \\
\text { taste in information and activities. }\end{array}$ \\
\cline { 2 - 3 } & $\begin{array}{l}\text { Social } \\
\text { assets }\end{array}$ & $\begin{array}{l}\text { The place provides a visualization of one's } \\
\text { social assets (friends, interactions, social } \\
\text { achievement) }\end{array}$ \\
\hline Liveliness & Activity & $\begin{array}{l}\text { If it stands still, it does not provide a } \\
\text { sense of comfort. People prefer activity } \\
\text { and liveliness, which gives them a sense of } \\
\text { life. The sense of stability and incremental } \\
\text { stable changes provide a live feeling of my } \\
\text { place. Sometimes, it requires the manage- } \\
\text { ment of pace and rhythms in order to avoid } \\
\text { monotony. }\end{array}$ \\
\hline Rewarding & $\begin{array}{l}\text { Positive } \\
\text { social } \\
\text { feedback }\end{array}$ & $\begin{array}{l}\text { Real-time, positive, and human feedback is } \\
\text { important for the feeling of being acknowl- } \\
\text { edged. }\end{array}$ \\
\cline { 2 - 3 } & $\begin{array}{l}\text { Positive } \\
\text { Psychology }\end{array}$ & $\begin{array}{l}\text { Five aspects of positive psychology (a) pos- } \\
\text { itive emotion, (b) engagement, (c) mean- } \\
\text { ing, (d) positive social relationship, and (e) } \\
\text { achievement, contribute to the well-being } \\
\text { of a person. }\end{array}$ \\
\hline
\end{tabular}

In addition to the improved literacy of social services, it is necessary to build up a sound framework that facilitates the design of a living place in the virtual world.

From the viewpoint of social service, Yamakami examined the reasons for quitting an SNS service. He categorized the reasons as depicted in Table II.

\section{DESIGN}

\section{A. Factors of comfortableness in my place}

The author analyzes the important factors for comfortableness in order to explore internally focused design.

Important factors for comfortableness in my place on the Internet are depicted in Table III. They are classified according to emotional factors.

First, my place should be secured, bringing a sense of safety. Safety means privacy and being protected. There should be no threats to privacy, for example, no daily concerns about unplanned privacy breaches. The sharing of privacy-related items is under the control of the user, with a good sense of controllability. No intruding messages or displays surprise the user. The user can connect with the persons he/she wants to 
TABLE IV

EXAMPLES OF FUNCTIONS IN MY PLACE

\begin{tabular}{|c|c|c|}
\hline $\begin{array}{l}\text { Emotional } \\
\text { factor }\end{array}$ & Factor & Function examples \\
\hline \multirow[t]{2}{*}{ Safety } & Security & $\begin{array}{l}\text { Easy authentication for login and submis- } \\
\text { sion. Control functions for friends and } \\
\text { community members. }\end{array}$ \\
\hline & Healing & $\begin{array}{l}\text { Function for expressing emotions and re- } \\
\text { ceiving feedback. }\end{array}$ \\
\hline \multirow[t]{2}{*}{ Me-ness } & $\begin{array}{l}\text { Taste- } \\
\text { matching }\end{array}$ & $\begin{array}{l}\text { Customizability and tailor-ability of visual } \\
\text { layout and content. }\end{array}$ \\
\hline & $\begin{array}{l}\text { Social } \\
\text { assets }\end{array}$ & $\begin{array}{l}\text { Function to display one's social assets } \\
\text { (friends, interactions, achievement with } \\
\text { collaboration). }\end{array}$ \\
\hline Liveliness & Activity & $\begin{array}{l}\text { Function to display activity. Function to en- } \\
\text { courage interactions with friends. Function } \\
\text { to provide touches to timely events and hot } \\
\text { topics of the external world. Function to } \\
\text { display one's own daily growth. Function } \\
\text { to display the degree of being socially } \\
\text { recognized. Function to link external ac- } \\
\text { tivities. }\end{array}$ \\
\hline \multirow[t]{2}{*}{ Rewarding } & $\begin{array}{l}\text { Positive } \\
\text { social } \\
\text { feedback }\end{array}$ & $\begin{array}{l}\text { Feeding activity to social networks. Count- } \\
\text { ing friends and comments from friends. }\end{array}$ \\
\hline & $\begin{array}{l}\text { Positive } \\
\text { Psychology }\end{array}$ & $\begin{array}{l}\text { Multimedia facility to provide enjoyment } \\
\text { (with some kind of surprise). Facility to } \\
\text { provide flow experience (balance of incom- } \\
\text { ing information and control). Facility to } \\
\text { provide meaning (especially, social mean- } \\
\text { ings). Facility to record and display one's } \\
\text { achievement (for one's activity and social } \\
\text { contribution) }\end{array}$ \\
\hline
\end{tabular}

connect with, and disconnect from the people he/she wants to avoid. The user does not have to deal with the anxiety of being incapable of controlling social interactions. Also, it can provide a healing place to hide when you are endangered by the harsh interactions on the Internet.

Second, my place should be tailored to one's taste. It is "my" place, after all, therefore it should be distinguished by one's special tastes and preferences.

Third, my place should be moderately active. It should not be too busy, but active and alive with incremental changes, hopefully accompanied by personal growth in ability and social interaction.

Fourth, my place should be rewarding to one's activities there. Positive social feedback is provided. Positive emotion, engagement, meaning, positive relationship, and achievement, are acknowledged or supported [11].

Examples of functions in my place are depicted in Table IV.

The four emotional drivers are classified according to two dimensions, as depicted in Fig. 2.

The two dimensions are: (a) closedness vs. openness, and (b) collective-focus vs. self-focus. The user's my-place-ness preference in the two-dimensional view model changes from time to time, depending on context.

Sometimes, a user is in a different mood, for example, (a) forward-moving, or (b) change of pace, or (c) healing. In the mood of forward-moving or change of pace, the user's preference of my-place-ness may shift toward more open, and more collective-focus domain. In the mood of healing, the user's preference may shift toward more closed, more self-

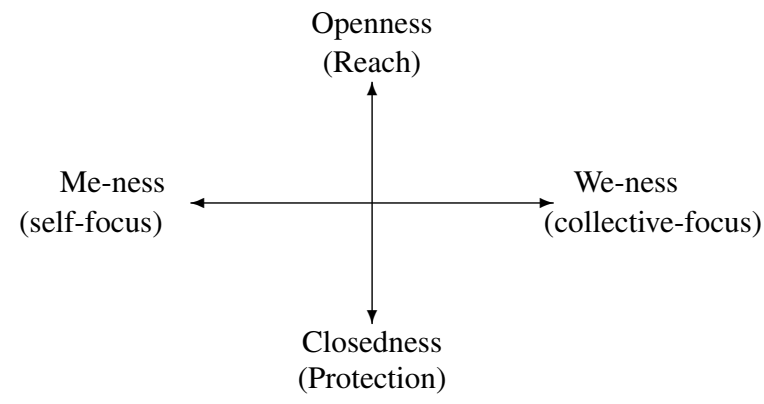

Fig. 2. A two-dimensional model of my-place-ness

TABLE $\mathrm{V}$

FACTORS THAT IMPACT ONE'S POSITION WITHIN MY-PLACE-NESS

\begin{tabular}{|l|l|}
\hline Factor & Description \\
\hline Mood & $\begin{array}{l}\text { A temporary mood impacts one's position within the my- } \\
\text { place-ness. }\end{array}$ \\
\hline Activity & Activity currently at hand impacts the position. \\
\hline Personality & Individual personality and tendency impacts the position. \\
\hline Culture & Cultural background impacts the position. \\
\hline $\begin{array}{l}\text { Online ex- } \\
\text { perience }\end{array}$ & $\begin{array}{l}\text { Short-term or long-term online social experience impacts } \\
\text { the position. }\end{array}$ \\
\hline Community & $\begin{array}{l}\text { Norms and behavior styles of a community with which } \\
\text { the user is currently engaged in impacts the position. }\end{array}$ \\
\hline
\end{tabular}

focus.

Contextual factors impact the choice of position in the myplace-ness domain. Some examples are depicted in Table V.

Considering this flexibility, it is important to design myplace-ness with controllability. From this viewpoint, the requirements of controlling my-place-ness are depicted in Table VI.

\section{B. Design Components}

The author described the logical components in earlier sections. The concrete artifacts that serve for my-place-ness in design are depicted in Fig. 3.

TABLE VI

REQUIREMENTS FROM THE VIEWPOINT OF CONTROLLABILITY OF MY-PLACE-NESS

\begin{tabular}{|l|l|}
\hline Requirement & Description \\
\hline Ease of use & $\begin{array}{l}\text { Ease of use of my-place-ness, without burdens or } \\
\text { stresses. }\end{array}$ \\
\hline Visualization & Ease of grasping the current set-up of my-place-ness. \\
\hline Controllability & $\begin{array}{l}\text { Ease of control of my-place-ness without disturbing pri- } \\
\text { vacy, security, and inconvenience of social interactions. } \\
\text { Providing a sense of control to the user. }\end{array}$ \\
\hline
\end{tabular}

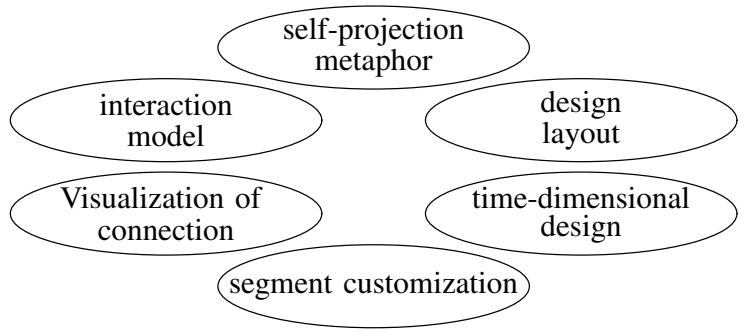

Fig. 3. Concrete artifacts for my-place-ness in design 


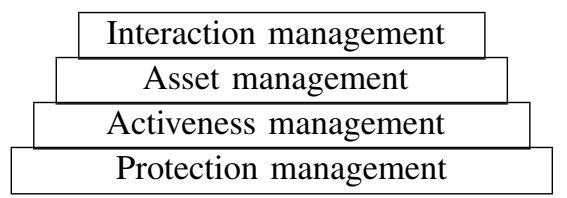

Fig. 4. A layered view model of my-place-ness on the Internet

First, the self-projection metaphor is a newly coined word for my-place-ness. The existing design focuses on the interface with the external world first. It carries the an implicit assumption that self is a stable and perfect entity, not a thing that design ordinarily deals with. How to present oneself for one's own view and social view is an important factor for engagement, shown in the design of mobile social games.

Second, the interaction model deals with interactions that take place in my-place. For twitter, it is a short-sentence update. For Facebook, it is a photo or timeline. This is the artifact that most social service design focuses on.

Third, design layout deals with attention and focus. It deals with social interactions, and personal assets and tastes.

Fourth, visualization of connection deals with explicit attention to social relationships.

Fifth, time-dimensional design deals with asynchronous events, long-term relationships. and achievements over a span of time.

Sixth, segmentation customization deals with event-specific, community-specific, activity-specific artifacts. For the practical design, it is important to fill this. However, it is beyond the scope of general my-place-ness.

These artifacts are the building blocks for the design of my-place-ness-oriented social services.

\section{Layered View Model}

A layered view model of my-place-ness on the Internet is depicted in Fig. 4.

First, the bottom layer, protection management, provides security and privacy control. This is functional and representational. The sense of protection requires visualization and feedback about controllability.

Second, the next layer, activeness management, provides production of activeness and liveliness. It needs to address content including social interactions, and tailoring of content for one's tastes. This functions as a temporary and contemporary border between me and the external world.

Third, the third layer, asset management, provides visualization of long-term accumulation of personal assets, such as goals and achievements, and, social relationships. This provides a visualization of self and rewarding feedback for one's growth.

Fourth, the top layer, interaction management, provides management and control of social interactions. This provides rewards such as positive personal feedback.

The existing framework only deals with the bottom layer from the technological viewpoint, and mainly deals with the fourth layer from the functional viewpoint. The proposed approach adds the second and third layers in order to address
TABLE VII

COMPARISON OF EXTROVERSIVE AND INTROVERSIVE APPROACHES

\begin{tabular}{|c|c|c|c|}
\hline Approach & Description & Pros & Cons \\
\hline Extroversive & $\begin{array}{l}\text { An approach that } \\
\text { focuses on technology- } \\
\text { augmented functions } \\
\text { and services. }\end{array}$ & $\begin{array}{|lr|}\text { Functions } r & \text { are } \\
\text { concrete } & \text { and } \\
\text { comprehensive. }\end{array}$ & $\begin{array}{l}\text { It has some negative } \\
\text { effects such as over- } \\
\text { implementation and } \\
\text { social fatigue. }\end{array}$ \\
\hline Introversive & $\begin{array}{l}\text { An approach that fo- } \\
\text { cuses on inner require- } \\
\text { ments of a human being }\end{array}$ & $\begin{array}{lr}\text { Capable } & \text { of } \\
\text { addressing inner } \\
\text { user experience. }\end{array}$ & 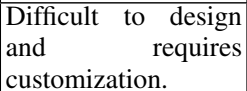 \\
\hline
\end{tabular}

TABLE VIII

COMPARISON OF MY-PLACE-NESS WITH OTHER EXTROVERSIVE APPROACHES

\begin{tabular}{|l|l|}
\hline Approach & Difference \\
\hline $\begin{array}{l}\text { Social activity } \\
\text { awareness }\end{array}$ & $\begin{array}{l}\text { The social activity awareness approach focuses on } \\
\text { increased awareness of ongoing activities. It is a part } \\
\text { of persuasive approaches. The proposed approach has } \\
\text { a wider scope and focuses on internal comfort, not the } \\
\text { single focus on external connections and activities. }\end{array}$ \\
\hline $\begin{array}{l}\text { Game-based } \\
\text { socialization }\end{array}$ & $\begin{array}{l}\text { A game is a combination of activity-based approaches } \\
\text { and goal-based-persuasion approaches. The proposed } \\
\text { approach provides guidance to prevent intrusiveness. }\end{array}$ \\
\hline Social graph & $\begin{array}{l}\text { The social graph approach focuses on interpersonal } \\
\text { relationships, and is based on the assumption that } \\
\text { interpersonal relationships determine interactions. The } \\
\text { proposed approach is relationship-neutral, therefore, } \\
\text { these approaches are orthogonal and complementary. }\end{array}$ \\
\hline Buzz market- & $\begin{array}{l}\text { The buzz marketing approach focuses on fast-spreading } \\
\text { hot topics, and is based on the assumption that hot items } \\
\text { ing } \\
\text { contl drive social diffusion. The proposed approach is } \\
\text { onal and complementary. }\end{array}$ \\
\hline
\end{tabular}

the introversive satisfaction of a user in order to prevent social burn out from the extroversive approach.

\section{DISCUSSION}

\section{A. The Advantages of the Proposed Approach}

There are two approaches in social service engineering: an extroversive approach and an introversive approach. The characteristics are depicted in Table VII.

The two approaches can complement each other.

The introversive approach can complement the drawbacks of the many existing extroversive approaches that cause social fatigue without considering the overload of social interaction. The introversive approach can provide design clues to prevent this drawback.

A comparison of my-place-ness with extroversive approaches in social services is depicted in Table VIII. The proposed introversive approach compensates for the overload of existing extroversive approaches.

A comparison of my-place-ness with other design frameworks is depicted in Table IX.

The proposed approach takes personal comfort into consideration in order to compensate for existing design frameworks. In the past, "social" as the new design factor attracted design patterns. In a retrospective view, these approaches underestimated human vulnerability in the virtual space. The proposed my-place-ness approach compensates for the existing hole in social service design. It highlights the importance of personal comfort with the awareness of social activities and relationships. 
TABLE IX

COMPARISON OF MY-PLACE-NESS WITH OTHER DESIGN FRAMEWORKS

\begin{tabular}{|l|l|}
\hline Framework & Difference \\
\hline $\begin{array}{l}\text { Personal } \\
\text { space } \\
\text { (proxemics) }\end{array}$ & $\begin{array}{l}\text { Personal space is the description of layered social dis- } \\
\text { tances in the physical space. Cognitive aspects in the } \\
\text { virtual world are not covered. }\end{array}$ \\
\hline $\begin{array}{l}\text { Affordance } \\
\text { theory }\end{array}$ & $\begin{array}{l}\text { Affordance provides a metaphor that describes the intu- } \\
\text { itive linkage to functions embedded in an artifact. This } \\
\text { provides a basis for dealing with ease of use in the context } \\
\text { of human-artifact interaction. It does not address the fine- } \\
\text { tuned cognitive aspects of a user. }\end{array}$ \\
\hline $\begin{array}{l}\text { Universal } \\
\text { design } \\
\text { theory }\end{array}$ & $\begin{array}{l}\text { Universal design provides a framework that can be used } \\
\text { by a person with a diverse set of capabilities. It does not } \\
\text { address the changes and rhythms in the cognitive aspects } \\
\text { of a user. }\end{array}$ \\
\hline $\begin{array}{l}\text { Gamenics } \\
\text { theory }\end{array}$ & $\begin{array}{l}\text { Gamenics theory deals with engagement, learn-ability } \\
\text { and enjoyment. It deals with external activation with a } \\
\text { wide range of game-based techniques including time- } \\
\text { dimensional management. It does not deal with sense of } \\
\text { self in an explicit way. }\end{array}$ \\
\hline
\end{tabular}

Human beings have evolved over a long span of time during which they developed a wide range of social and cultural protection for my-place-ness in the physical environment. Now, they are living in the era of the Internet where they interact with an increasing number of different types of people. At the same time, the bonds with surrounding people are getting thinner and being diluted.

To cope with these trends, it is necessary to establish a design methodology to rebuild my-place-ness in the services of the virtual world.

\section{B. Limitations}

This research is a qualitative study. The quantitative measures for identifying and evaluating many of the aspects of the my place theory discussed in this paper remain for further study.

User acceptance of the design of the my place theory in the real world environment is beyond the scope of this paper. Quantitative analysis of performance and user satisfaction of my place theory-empowered design requires future research.

The concrete design methodology of the my place theory is beyond the scope of this paper.

The proposed approach only describes dimensions and layers. Quantitative metrics for my-place-ness in each aspect are not covered in this paper.

\section{CONCLUSION}

The author discusses my-place-ness as a building block in the design of social services. My-place-ness provides an intrinsic approach for usability and comfort of services that deal with social interaction on the Internet.

First, the author argues that there are many traces of my-place-ness that can be found in the past evolution of Internet services. Then, the author discusses the comparison of an intrinsic design approach using my-place-ness and an extrinsic design approach that focuses on functionality in the social context. My-place-ness provides a basis for an intrinsic approach that deals with the emotional aspects of the design of social services. The author discusses factors of my-place-ness to provide design criteria for social services from an intrinsic design approach.

My-place-ness is a key factor for dealing with the digitaldivide. One of the applications of my-place-ness will be a social service for senior citizens that will facilitate coping with the emerging digital-divide issues. The digital-divide is increasing due to advances in smartphones that provide a package of PC features that can overwhelm many senior citizens.

The author describes the four aspects of my-place-ness, then, he provides a two-dimensional view model of my-placeness. Finally, the author provides a layered view of a function model that provides the my-place-ness. It provides a basis for building blocks of social services from an introversive viewpoint that compensates for the existing extroversive design of social services.

\section{REFERENCES}

[1] S. Harrison and P. Dourish, "Re-place-ing space: the roles of place and space in collaborative systems," in ACM CSCW'96, November 1996, pp. 67-76.

[2] P. E. Agre, "Changing places: contexts of awareness in computing," Hum.-Comput. Interact., vol. 16, no. 2, pp. 177-192, Dec. 2001.

[3] P. Dourish, "Re-space-ing place: "place" and "space" ten years on," in Proceedings of the 2006 20th anniversary conference on Computer supported cooperative work, ser. CSCW '06. New York, NY, USA: ACM, 2006, pp. 299-308.

[4] J. McCarthy and P. Wright, "Technology in place: dialogics of technology, place and self," in Proceedings of the 2005 IFIP TC13 international conference on Human-Computer Interaction, ser. INTERACT'05. Berlin, Heidelberg: Springer-Verlag, 2005, pp. 914-926.

[5] D. Knox and S. Fincher, "Why does place matter?" in Proceedings of the 18th ACM conference on Innovation and technology in computer science education, ser. ITiCSE '13. New York, NY, USA: ACM, 2013, pp. 171-176.

[6] E. Bjerrum and S. Bødker, "Learning and living in the 'new office'," in Proceedings of the eighth conference on European Conference on Computer Supported Cooperative Work, ser. ECSCW'03. Norwell, MA, USA: Kluwer Academic Publishers, 2003, pp. 199-218.

[7] L. Lentini and F. Decortis, "Space and places: when interacting with and in physical space becomes a meaningful experience," Personal Ubiquitous Comput., vol. 14, no. 5, pp. 407-415, Jul. 2010.

[8] A. Antonopoulou, "Living in second life versus acting in flash mob: re thinking place through virtual and urban play," in Proceedings of the 2010 international conference on The Interaction Design, ser. Create'10. Swinton, UK, UK: British Computer Society, 2010, pp. 109-109.

[9] T. Yamakami, "Towards understanding sns fatigue: Exploration of social experience in the virtual world," in ICCIT 2012. IEEE CPS, December 2012, pp. 227-231.

[10] S. Tazghini and K. L. Siedlecki, "A mixed method approach to examining facebook use and its relationship to self-esteem," Comput. Hum. Behav., vol. 29, no. 3, pp. 827-832, May 2013.

[11] M. Seligman, Flourish: Avisionoary new understanding of happiness and well-being. New York, NY, U.S.A.: Free Press, 2011.

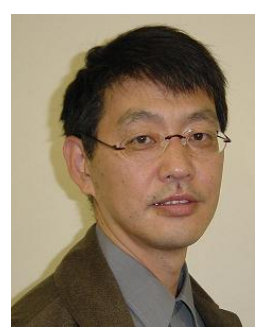

Toshihiko Yamakami received the B.E.I.S. and M.S.I.S. from University of Tokyo, Japan, in 1982 and 1984 respectively. He received the Ph.D. degree in reliability information system engineering from Kagawa University, Japan, in 2007. He was engaged in International standardization of systems in the application layer and mobile Webs in ISO, W3C, and WAP(OMA). His research interests include service engineering, gamification, and organizational knowledge and change management. He is a Senior specialist at ACCESS, Japan. He has been a member of the ACM since 1982, and is its life-time member. He obtained the IPSJ Yamashita Award in 1995. He published 150 international conference papers. 